Article

\title{
Reducing the Bitter Taste of Virgin Olive Oil Don Carlo by Microbial and Vegetable Enzymes Linked to the Colloidal Fraction
}

\author{
Biagi Angelo Zullo ${ }^{1}$, Silverio Pachioli ${ }^{2}$ and Gino Ciafardini ${ }^{1, *}$ \\ 1 Department of Agricultural, Environmental and Food Sciences, University of Molise, Via De Sanctis, \\ I-86100 Campobasso, Italy; biagi.zullo@unimol.it \\ 2 Agricultural Technical Institute "Cosimo Ridolfi", Via Colle Comune n.1, I-66020 Scerni, Italy; \\ silveriopachioli@libero.it \\ * Correspondence: ciafardi@unimol.it; Tel.: +39-087-4404-689
}

Received: 16 December 2019; Accepted: 24 February 2020; Published: 28 February 2020

\begin{abstract}
Bitter taste is a positive sensory attribute that correlates with the concentration of phenols in olive oil. However, excessive bitterness can be perceived by consumers as a negative attribute. The aim of this investigation was to improve the process of debittering Don Carlo extra virgin olive oil (EVOO), which is rich in phenols, through blending with newly produced Leccino EVOOs, which can provide high oleuropeinolytic activity. The debittering process of blending Don Carlo EVOO with two types of Leccino EVOOs (decanter and settled EVOO), was carried out during three months of storage in canisters placed in fixed positions, or periodically inverted to prevent sedimentation. The reduction in phenolic concentration and bitterness index (K225 value) reached maximum values of $51 \%$ and $42 \%$ respectively in Don Carlo EVOO mixed with Leccino settled EVOO after three months of storage in periodically inverted containers. Analytical indices and sensory analysis, in accord with bitterness index (K225) results, confirmed a reduction or elimination of bitter taste in the oil samples depending on the type of Leccino EVOO added, and the sample storage method. All analytical results remained within parameters established by the European Community regulations for commercial merceological class EVOO.
\end{abstract}

Keywords: $\beta$-glucosidase; bitterness; debittering process; extra virgin olive oil; oleuropeinolytic yeasts; phenol oxidase

\section{Introduction}

Extra virgin olive oil (EVOO), one of the oldest known vegetable oils, is a staple of the Mediterranean diet and is well known worldwide for its sensory and nutritional value [1]. The health benefits of olive oil have been officially recognized by the European Food Safety Authority (EFSA) with a health claim that attributes protection of blood lipids from oxidative stress to the phenols in virgin olive oil [2]. Freshly produced EVOO is characterized by opalescence, due to the presence of micro-droplets of vegetation water, and solid particles from the fruits. Veiled fresh EVOO is a water-oil emulsion in which different substances, including phenols, proteins, sugars, and emulsifying agents (phospholipids and mono- and diacylglycerols) participating in colloid formation aggregate at the oil/vegetation water interface [3-5]. The solid particles and water in fresh produced EVOO allow the survival of microorganisms, primarily yeasts, that migrate into the oil together with the olive fragments and vegetation water during the extraction process, and reproduces in a selective manner in accordance with the physicochemical composition of the medium [6]. Lercker et al. [7] reported a nitrogen content of $0.6 \%$ in wet deposit waste, most likely in the form of proteins, while Koidis and Boskou [8] found protein levels below $2.5 \mathrm{mg} / \mathrm{Kg}$ of veiled olive oil. Georgalaki et al. [9] demonstrated detectable amounts 
of protein, including hydrolytic and oxidative enzymes (such as lipoxygenase and phenoloxidase activities) in EVOO. These enzymes may reduce the "pungent" and "bitter" sensory notes, the intensity of which is strictly linked to the content of secoiridoids [10-12]. Remarkable secoiridoids include oleuropein, ligstroside and dimethyl oleuropein, as well as their phenolic derivatives and hydrolysis products, which include oleuropein aglycone, ligstroside aglycone, oleacein, and oleocanthal [13,14]. Ciafardini and Zullo [6] demonstrated that yeasts' activity in EVOO can conditions the sensory properties of the product through production of $\beta$-glucosidase. In fact, the enzymes active in newly produced EVOO can be derived from the olive fruit $[15,16]$, and also from the microorganisms entrapped in droplets of vegetation water suspended in the oil [6,17-19]. These microbial and vegetable enzymes may exert positive effects on the sensory characteristics of the newly produced EVOO by promoting debittering through $\beta$-glucosidase and esterase activities, which act on the olive oil bitter glucoside oleuropein and its derivative oleuropein aglycone, respectively [6]. Some Italian olive varieties, including Coratina, Don Carlo, F-17, and Giulia, normally produce bitter-pungent virgin olive oil with a medium-high content of phenols, which are used to raise the phenolic content of other EVOO through blending. Bitter taste is a positive sensory attribute in EVOO, however excessive bitterness can be negatively perceived by consumers [20]. To avoid production of olive oil with an unwanted bitter taste, studies have been carried out, which have included immersion of olives in hot water before oil extraction $[21,22]$ or oil washing with a liquid-liquid phenol extraction procedure in water [23,24]. Washing with water to reduce bitterness unfortunately also indiscriminately reduces a substantial fraction of desirable phenolic compounds from olive oil. The above monocultivar EVOOs, with high bitter taste, can be consumed directly after a racking operation, which generally reduces the oil's bitter character due to enzymatic hydrolysis of oleuropein. In detail, racking is performed by storing fresh produced EVOO in tanks, allowing it to settle for 5-6 months, during which time the oxidizing and oleuropeinolytic enzymes ( $\beta$-glucosidase and esterase) both linked to the oil colloidal fraction, degrade some of the phenolic compounds in the oil fraction improving its sensory characteristics. This system has known drawbacks, such as those described below, which discourage its use. First, storage of oil for long periods before marketing is a problem for the industry, that risks alteration of the EVOO due to activity of microbes that accumulate at the bottom of the tank. Another liability is that in many cases, EVOOs subjected to racking for several months remain bitter after treatment due to their low enzyme and yeasts contents. Taking into account the problems described above, the aim of this work was to improve the debittering process of Don Carlo EVOO, by blending with other types of EVOO that contain high oleuropeinolytic activity due to microbial and vegetable enzymes linked to their oil colloidal fractions.

\section{Materials and Methods}

\subsection{Production of Phenol Rich Monocultivar EVOO for Debittering Assays}

Phenol-rich EVOOs were extracted from the ancestral cultivar Coratina, widespread for hundreds of years in central-southern Italy, and three new genetically improved Italian cultivars introduced in the last ten years: Don Carlo, Giulia, and FS-17. EVOO with different total polar phenol contents generated from the Coratina, Don Carlo, Giulia, and FS-17 cultivars were collected during the 2018 harvest from mills located in the rural area of Molise (Central Italy). Homogeneous masses of approximately $300 \mathrm{Kg}$ of healthy olives from the same rural area were separately processed within $12 \mathrm{~h}$ of harvest. After removing leaves and other materials, the olives were washed in fresh tap water. The fruits were crushed at $2000 \mathrm{rpm}$ with a grinder, and the paste obtained underwent malaxation for $20 \mathrm{~min}$ at $27^{\circ} \mathrm{C}$. The paste was then moistened with a small amount of tap water. Double extraction through horizontal (decanter) and vertical centrifugation then separated the oil from the other components of the fruits. The unfiltered veiled fresh produced EVOO from each cultivar were stored separately in four batches and subjected to physico-chemical and microbiological assays, using four samples transferred from each cultivar into sterile Pyrex flasks equipped with screw caps. The mono EVOO cultivar with the 
highest bitter index (B.I. K225) and total polar phenols content was chosen for the debittering trials described below.

\subsection{Production of Settled and Decanter Leccino EVOO for Blending}

Leccino EVOO was produced using the same type of mill, and the same quantity of fruit, harvested from the geographical area described above. With the intent of increasing the suspended fraction in the veiled Leccino EVOO, batches of oil for blending were obtained directly from the EVOO decanter without subjecting them to vertical centrifugation. This oil was termed "decanter EVOO". While a batch of settled EVOO obtained from horizontal and vertical extraction was termed "settled EVOO". The decanter oil was prepared by taking four $20 \mathrm{~L}$ batches of oil and vegetation water directly from the decanter before subjecting to vertical centrifugation. After $24 \mathrm{~h}$ of storage, the EVOO that separated from the residual vegetation water collected at the bottom, was transferred into four empty canisters, and analysed to ascertain its physico-chemical and microbiological properties, then closed hermetically. During storage (20 days), the canisters with decanter EVOO were inverted every 7 days to prevent sedimentation of the materials suspended in the oil. Settled EVOO, as reported before, was prepared using Leccino EVOO obtained by horizontal extraction (decanter) and vertical centrifugation. Four $20 \mathrm{~L}$ batches EVOO were placed in closed steel tanks and subjected to sedimentation for about 20 days. At the end of storage, the oils located in the medium-high area of each container were gently siphoned, leaving a bottom layer about $10 \mathrm{~cm}$ thick. These latter fractions, after verification of its characteristics by the above analyses, were gently siphoned and combined into a single batch, which constituted the settled EVOO used for blending.

\subsection{Blending of Phenol-Rich EVOO with Settled or Decanter Leccino EVOO}

The phenol-rich monocultivar EVOO chosen for debittering through blending was Don Carlo EVOO based on its highest B.I. (K225) and phenolic content. In detail, from the batch of freshly produced veiled olive oil twenty-four hermetically closed commercial metallic canisters containing 5 L of EVOO were prepared. Tested conditions were as follows: (1) Don Carlo EVOO blended with 20\% settled Leccino EVOO (8 canisters); (2) Don Carlo EVOO blended with 20\% decanter Leccino EVOO (8 canisters); (3) Pure Don Carlo EVOO (8 canisters, control). Each treatment group, including the untreated control, was sub-divided into two groups: the first group was stored in a fixed position for 3 months, while the second was stored for 3 months under the same conditions, but the canisters were inverted every 7 days. A manual rotary forklift (LLOLDI, Reggio Emilia, Italy) suitable for simultaneously inverting four canisters was used to impede sedimentation of the suspended materials. Each treatment was repeated four times. Olive oil sub-samples were collected from each $5 \mathrm{~L}$ canister at the beginning of the experiment (time zero) and again after 3 months of storage at $15-16{ }^{\circ} \mathrm{C}$.

\subsection{Enzymatic Analysis of the EVOO}

Among the enzymes responsible for hydrolysis and oxidation of the EVOO phenolic compounds, both $\beta$-glucosidase and phenol oxidase activities have been studied. The activity of these two enzymes was assessed in the suspended fraction of the Leccino EVOO decanter and settled EVOO mixer fractions.

\section{5. $\beta$-Glucosidase Activity}

Thirty mL samples of EVOO were microfiltered through nitrocellulose filters with a pore size of 0.45 $\mu \mathrm{m}$ (Minisart NML, Sartorius, Göttingen, Germany). Nitrocellulose filters containing the suspended materials from the oil samples were transferred in to $25 \mathrm{~mL}$ beakers, where they were homogenized with a Turrax mod. T25 homogenizer (IKA, Milan, Italy) in the presence of $12 \mathrm{~mL}$ of phosphate buffer, $0.1 \mathrm{M}, \mathrm{pH}$ 7. The crude enzymatic extract was divided into two $6 \mathrm{~mL}$ aliquots. One was enriched with $0.4 \%(w / v)$ synthetic substrate 4-nitrophenyl $\beta$-D-glucopyranoside (Sigma-Aldrich, Saint Louis, MO, USA) while the sample without the substrate served as control. After a 20 min incubation at $30{ }^{\circ} \mathrm{C}$, both samples were centrifuged at $12000 \times g$ for $5 \mathrm{~min}$, then supernatants were separately filtered 
through Millex syringe filters with a pore size of $0.22 \mu \mathrm{m}$ (Merck Millipore Ltd., Tullagreen, Ireland), and analyzed at $410 \mathrm{~nm}$ with a spectrophotometer (Jenway mod. 6300, Essex, UK). The instrument was calibrated with the control oil. Enzymatic analyses performed on each sample were repeated three times.

\subsection{Phenol Oxidase Assay}

Phenoloxidase activity was evaluated using a spectrophotometric method based on an initial rate of increase in absorbance at $410 \mathrm{~nm}$ [25]. The phenoloxidase assay used pyrocatechol (Sigma-Aldrich) as substrate. Thirty $\mathrm{mL}$ of each Leccino EVOO mixer sample was microfiltered through a nitrocellulose filter with a pore size of $0.45 \mu \mathrm{m}$. Twelve $\mathrm{mL}$ of crude enzymatic extract was obtained, as before. Immediately prior to assay, the crude enzymatic extract of each EVOO sample was centrifuged at 12000x $g$ for $5 \mathrm{~min}$, and supernatants were filtered with Millex syringe filters with a pore size of $0.22 \mu \mathrm{m}$, then diluted 20 times by transferring $200 \mu \mathrm{L}$ of sample into a spectrophotometer cuvette containing $3.8 \mathrm{~mL}$ of phosphate buffer, $0.1 \mathrm{M}, \mathrm{pH} 6.2$, and $100 \mathrm{mM}$ pyrocatechol. Spectrophotometer data was collected with a time interval of $30 \mathrm{~s}$ for $5 \mathrm{~min}$ at $410 \mathrm{~nm}$. Reaction rates were calculated from initial linear regions of the absorbance vs. time graphs. In the above experiments, extractions were repeated twice and 2 samples from each extract were assayed. One unit of phenoloxidase activity (U) was defined as a 0.01 change in absorbance at $410 \mathrm{~nm}$ under given conditions per min.

\subsection{Microbiological Analysis}

Microbiological analyses were performed on oils extracted from the decanter and settled EVOO used as oil-mixers and on the blended Don Carlo EVOO, at the beginning of the experiment, and after 3 months of storage. Microbiological analyses were accomplished using $100 \mathrm{~mL}$ of sample, as described by Zullo et al. [26]. In detail, $10 \mathrm{~mL}$ oil samples were micro-filtered through sterile nitrocellulose filters with a pore size of $0.45 \mu \mathrm{m}$. The nitrocellulose filter used to capture each sample was then transferred into a $25 \mathrm{~mL}$ sterile beaker and homogenized with a Turrax model T25 homogenizer (IKA) in a sterile physiological solution. Finally, the initial weight of each sample was reconstituted through addition of a sterile physiological solution and used to make 10-fold serial dilutions in a sterile physiological $0.9 \%$ $(w / v) \mathrm{NaCl}$ solution. Yeasts were detected using Petri dishes with MYGP agar medium containing the following: $3 \mathrm{~g}$ yeast extract (Biolife, Milan, Italy), $3 \mathrm{~g}$ malt extract (BBL, Cockeysville, MD, USA), $5 \mathrm{~g}$ phytone powder (BBL), $10 \mathrm{~g}$ D-glucose (Merck, Darmstadt, Germany), and $1000 \mathrm{~mL}$ distilled water, $\mathrm{pH}$ 7 , as described by Kurtzman and Fell [27]. This medium was supplemented with tetracycline $(20 \mathrm{mg} / \mathrm{L})$ to inhibit bacterial growth. Two hundred $\mu \mathrm{L}$ of each dilution, was plated onto the above specified growth media for colony counting in triplicate, using spread plating. Yeast colonies were counted after 5 days incubation at $30^{\circ} \mathrm{C}$, then transferred into Petri dishes to prepare several master plates with the same medium [28] for use in the trials described below.

\section{8. $\beta$-Glucosidase and Phenoloxidase Producing Yeasts}

Ninety five colonies were chosen at random from the single masters obtained from microbiological analysis of each oil sample to ascertain numbers of $\beta$-glucosidase and phenoloxidase-producing yeasts. The number of $\beta$-glucosidase-producing yeasts was evaluated by transferring yeast cells into a sterile 96-well microplate containing $150 \mu \mathrm{L} /$ well of $0.1 \mathrm{M}$ phosphate buffer $\mathrm{pH} 7$ enriched with $0.4 \%(w / v)$ 4-nitrophenyl $\beta$-D-glucopyranoside (Sigma-Aldrich). One well per microplate, containing $150 \mu \mathrm{L}$ of $0.1 \mathrm{M}$ phosphate buffer $\mathrm{pH} 7$ enriched with the specific substrate without adding yeast, was used as a control. After $20 \mathrm{~min}$ of incubation at $30^{\circ} \mathrm{C}, \beta$-glucosidase activity was evaluated directly by assessing each well for yellow staining. Each assay was performed in duplicate. Phenoloxidase activity was assessed in sterile 96-well microplates, by suspending a small amount of yeast cells from the master in $150 \mu \mathrm{L}$ of $0.1 \mathrm{M}$ phosphate buffer $\mathrm{pH} 6.2$ containing $1.1 \%(w / v)$ of pyrocatechol (Sigma-Aldrich). One well in each microplate, containing all media components but excluding yeast, was used as a control. After $60 \mathrm{~min}$ of incubation at $30^{\circ} \mathrm{C}$, enzyme activity was evaluated based on the extent of 
dark colouring in the wells. Percentages of yeasts producing $\beta$-glucosidase and phenoloxidase were calculated as follows: $\% \beta$-glucosidase or phenoloxidase-producing yeasts $=$ (number of positive colonies/number of colonies examined) $\times 100$.

\subsection{Yeast Biodiversity Assessment}

The biodiversity of the different yeasts isolated from the blended Don Carlo EVOO after three months of storage was ascertained by screening a high number of yeast colonies grown on a specific chromogenic medium, which released colored compounds according to the physiological properties of the isolated yeasts. All yeast colonies isolated from the masters described previously were picked and inoculated onto Petri dishes containing CHROMagar Candida medium (cod. 4354093, BBL, MD, USA). Colony morphology of approximately 3000 colored yeast colonies was assessed after 7 days of incubation at $30^{\circ} \mathrm{C}$, as reported by Tornai-Lehoczki et al. [29]. All yeast colonies inoculated onto Petri dishes containing the chromogenic medium were selected and collected into five chromogenically homogeneous groups with the following characteristics: A; uniform bluish, B; fire red center with white exterior, C; uniform light brown, D; uniform green, and E; uniform white. From each chromogenic yeast colony group, 20 isolates were randomly chosen and used for subsequent identification of yeast species. The selected yeast colonies, belonging to different chromogenic groups, were subjected to genetic analysis and identified at the species level by sequencing the approximately 600 base-pair D1/D2 region of the large (26S) ribosomal subunit using primers NL1 and NL4, as described by Kurtzman and Robnett [30]. The ribosomal sequence from the NL1 primer was compared to those of published yeast species available in public sequence databases, using a BLAST search of call GenBank + EMBL+DDBJ+PDB sequence, on the NCBI website http://www.ncbi.nlm.nich.gov/blast.

\subsection{Suspended Materials}

Suspended materials from the four monocultivar EVOOs characterized by a high B.I. (K225) and phenol content, and the Leccino EVOOs mixer were evaluated. Thirty $\mathrm{mL}$ of each oil sample was filtered under reduced pressure using a pre-weighed nitrocellulose filter with a pore size of $0.45 \mu \mathrm{m}$. More specifically, each nitrocellulose filter was mounted on a filter holder, wetted with $1 \mathrm{~mL}$ of microfiltered olive oil, and subjected to reduced pressure to remove excess oil, then weighed using an analytical balance, mounted again on the filter holder, and used for sample filtration. Finally, filters were weighed again and weight differences were recorded. These analyses were performed in triplicate for each oil sample.

\subsection{Total Phenols}

Total polar phenolic content was evaluated according to Folin-Ciocalteu's procedure. Phenolic compounds were extracted from the EVOO as reported by Montedoro et al. [15], and quantitated at $765 \mathrm{~nm}$ using a Jenway mod. 6300 spectrophotometer. Analyses of each EVOO were performed in triplicate, and total polar phenols are expressed as $\mathrm{mg}$ caffeic acid equivalent (CAE) per $\mathrm{kg}$ oil (calibration curve with $\mathrm{r}^{2}=0.996$ ).

\subsection{Bitterness Index (K225)}

Three $\mathrm{mL}$ EVOO samples were transferred into $10 \mathrm{~mL}$ Pyrex tubes equipped with screw caps and containing $2.76 \mathrm{~mL}$ of extractant mixture consisting of methanol and water 80:20 $(v / v)$. Mixtures were stirred for $5 \mathrm{~min}$ by vortex, then centrifuged at $8000 \times \mathrm{g}$ for $10 \mathrm{~min}$. One hundred $\mu \mathrm{L}$ of phenolic extract was diluted in $2.4 \mathrm{~mL}$ of a 1:1 $(v / v)$ mixture of methanol and water and analyzed with a spectrophotometer (Kontron, Milan, Italy) at a wavelength of $225 \mathrm{~nm}$. Analysis of each EVOO sample were performed in triplicate. 


\subsection{Analytical Indices and Sensory Analyses}

Free fatty acid concentrations, peroxide values, and UV spectrophotometric indices $\left(\mathrm{K}_{232}, \mathrm{~K}_{270}\right.$, $\Delta K$ extinction coefficient $K_{266}$ and $K_{274}$ ) were evaluated by analyzing all EVOO samples to assess their commercial merceological class. All parameters were measured in triplicate for each sample according to European Community Regulation 1348/2013 [31]. Sensory analyses were performed on each blended EVOO by a fully trained analytical taste panel recognized by the Italian Ministry of Agriculture. The panel test was established using an IOC standard profile sheet method [32]. Each taster analyzed all samples during three different sessions. The median values of the sensory data were calculated, and the test supervisor chose a significance level of $5 \%$.

\subsection{Statistical Analysis}

A priori one-way analysis of variance, using Tukey's HSD (honest significant difference) test, was performed using the Statgraphics computer program (Statgraphics, version 6, Manugistics, Inc. Rockville, MA). Statistical significance was indicated at $p<0.05$.

\section{Results and Discussion}

EVOO is appreciated as a salad oil and for frying, for its delicious and equilibrate taste. The chemical analyses performed on the four monocultivar phenol-rich EVOO indicated a high phenolic concentration and B.I. (K225) ranging from a minimum of $478 \mathrm{mg}$ CAE per $\mathrm{Kg}$ (Coratina) to a maximum of $708 \mathrm{mg}$ CAE per Kg (Don Carlo) and 2.402 (Coratina) and 2.771 (Don Carlo) respectively. In accordance with the chemical results, the sensory analyses confirmed the higher bitterness and pungency of the Don Carlo cultivar EVOO compared to those of the EVOOs extracted from the other cultivars (Table 1). On the other hand, chemical and sensory analyses of the monocultivar EVOOs showed, in according with other findings, a positive relationship between the level of B.I. (K225) and the bitterness highlighted by the sensory profile $[20,33,34]$. The results demonstrate that, in some geographical areas such as those chosen for these experiments, the EVOO of the Coratina, which is an Italian ancestral cultivar known for its high phenolic content and bitter taste, can be exceeded by other EVOOs extracted from newly introduced cultivars genetically selected for other parameters.

\subsection{Laboratory Debittering Tests}

Since the EVOOs with high phenols content and bitter taste can be consumed directly only after having undergone a debittering process during several months of storage, considering the higher phenolic content and bitter taste of the oils studied, the EVOO of the Don Carlo cultivar was chosen as the most suitable cultivar for trials of debittering by blending with two types of Leccino EVOO. Among the Leccino EVOOs used as a mixer, the settled oil showed a higher content of suspended materials than the decanter EVOO, and higher $\beta$-glucosidase and phenoloxidase activity, while phenol concentrations were lower. The microbiota of both oils consisted of highly oleuropeinolytic yeasts with 96 and $98 \% \beta$-glucosidase producers, respectively in decanter and settled EVOO. In contrast, the concentration of phenoloxidase-producing yeasts was rather low and varied from 3 (decanter EVOO) to $11 \%$ (settled EVOO) (Table 2). The data in Table 2 show no significant difference between the number of oleuropeinolytic yeast cells (CFU), found in the two oils. Based on these results, it is possible to attribute the greater enzyme activity shown by the settled EVOO, to its higher content of enzyme-rich suspended material coming from the fruit.

\subsection{Microbiological Analysis and Yeast Biodiversity}

Microbiological analyses performed on the Don Carlo EVOO blended differently and stored for three months, indicated the presence of yeasts in all samples analyzed. More specifically, compared to the unmixed oil (control), at the beginning of the trial, the use of Leccino EVOO decanter and settled EVOO, increased the number of yeasts in the blended Don Carlo EVOO. This result was confirmed 
after three months of storage, only when the blended Don Carlo canisters were inverted periodically to impede sedimentation of suspended materials (Table 3). The concentration of $\beta$-glucosidase-producing yeasts was high throughout storage, varying from a minimum of $92 \%$ to a maximum of $100 \%$ of tested yeasts. In contrast, the percentage of phenoloxidase-producing yeasts was low in all samples and reached an overall maximum value of $19 \%$. The community of yeast species grown in oil during storage was influenced by blending. In fact, in the non-mixed Don Carlo EVOO (control) the predominant yeast species (about $78 \%$ prevalence) was Candida adriatica, while in the same oil subjected to blending, Candida diddensiae and C. adriatica were found in approximately $40 \%$ and $55 \%$ prevalence respectively, regardless of the sample preservation system (Table 3). Considering the previously reported antimicrobial activity of the EVOOs' polar phenols [35], the lower number of yeasts found in unmixed Don Carlo EVOO, compared to the Leccino's EVOO mixer, could be related to the different concentrations of total polar phenols found in the two oils, reported in Tables 2 and 3 . In fact, the greater phenolic concentration of the no mixed Don Carlo EVOO (about 4-5 times higher than that of the Leccino EVOOs; Tables 2 and 3) places strong selective pressure on the surviving yeasts in the oily fraction, allowing the growth of a few yeast species such as C. adriatica in the non-mixed Don Carlo EVOO or C. adriatica and C. diddensiae in mixtures with lower polar phenols level. The reduced number of yeasts recorded during the three month incubation of EVOOs stored in canisters fixed in a vertical position, cannot be attributed to cell death, but to their disappearance from the oily fraction, linked to the solid particles sedimentation to the bottom of the canisters [36].

\subsection{Physicochemical Analysis}

Total phenols concentration and the B.I. (K225), after three months of storage, were significantly lower in the blended Don Carlo EVOO compared to the non-mixed control, independently of sample preservation system. The greater reduction in both parameters was recorded, after three months of storage, when the Don Carlo EVOO was blended with settled Leccino EVOO. In fact, the total phenol concentration dropped from $588 \mathrm{mg}$ CAE per $\mathrm{Kg}$ to 411.48 and $285.74 \mathrm{mg}$ CAE per $\mathrm{Kg}$, while B.I. (K225) was reduced from 2.301 to 1.784 and 1.339 respectively, depending on the samples storage system. Among sample storage system, the use of periodically inverted canisters caused a significant reduction in phenolic content and B.I. (K225) in the blended Don Carlo EVOO, compared to the same samples stored in fixed canisters (Table 4). The results herein reported show that the hydrolytic and oxidative enzymes in unfiltered EVOOs are able to modify the physicochemical and sensory characteristics of the product, reducing its excessive bitter taste. However, Table 4 indicates that in the non-mixed Don Carlo EVOO, in three months of storage, the B.I. (K225) was reduced by just $11-12 \%$. On contrast, the same oil subjected to blending showed a strong reduction in B.I. (K225), $22-42 \%$ depending on storage system. This result was confirmed by sensory analysis of the same samples, which demonstrated the complete debittering of Don Carlo EVOO blended with settled Leccino EVOO, after three months of storage in periodically inverted canisters (Table 5). The storage of oil samples in periodically inverted canisters proved to be one of the best systems to shorten EVOO debittering by blending times. In fact, as previously elucidated by Zullo and Ciafardini [36] for production of unfiltered long veiled virgin olive oils, this system favours microbial activity in the oil, preventing yeast sedimentation with suspended material during storage.

\subsection{Qualitative Indices}

Sensory analysis of oils before and after three months of storage showed a significant reduction in bitterness and pungency in the blended Don Carlo EVOO, while no defects were found in any samples analyzed (Table 5). The analytical indices showed a slight increase in acidity and peroxides levels in Don Carlo EVOO blended with settled Leccino EVOO and preserved in periodically inverted canisters (Table 6). However, after three months of storage, both sensory analysis results and analytical indices were well within the allowed EVOO tolerances set by EC Regulations (Tables 5 and 6). 
Table 1. Physicochemical and sensory profiles of four monocultivar EVOO characterized by high Bitter Index and total phenols used as a blending source.

\begin{tabular}{|c|c|c|c|c|c|c|c|c|}
\hline \multirow[b]{2}{*}{ Cultivar } & \multirow{2}{*}{$\begin{array}{l}\text { Suspended } \\
\text { Material (\%) }\end{array}$} & \multicolumn{2}{|c|}{ Phenolic Characteristics } & \multicolumn{4}{|c|}{ Sensory Profile } & \multirow{2}{*}{$\begin{array}{c}\text { Merceologica } \\
\text { Class ** }\end{array}$} \\
\hline & & $\begin{array}{l}\text { Total Polar Phenols } \\
\text { (mg CAE per kg) }\end{array}$ & B.I. $\left(\mathrm{ABS}_{225}\right)$ & Fruitiness * & Bitterness & Pungency & Defects & \\
\hline Coratina & $0.033 \pm 0.008^{\mathrm{ns}}$ & $478 \pm 20.17^{\mathrm{c}}$ & $2.402 \pm 0.006^{b}$ & $2.70 \pm 0.19^{\mathrm{a}}$ & $2.70 \pm 0.17^{b}$ & $2.36 \pm 0.19^{b}$ & 0 & EVOO \\
\hline Don Carlo & $0.040 \pm 0.001^{\mathrm{ns}}$ & $708 \pm 10.01^{\mathrm{a}}$ & $2.771 \pm 0.001^{\mathrm{a}}$ & $4.70 \pm 0.13^{\mathrm{a}}$ & $4.80 \pm 0.31^{\mathrm{a}}$ & $3.70 \pm 0.24^{\mathrm{a}}$ & 0 & EVOO \\
\hline Giulia & $0.033 \pm 0.003^{\mathrm{ns}}$ & $492 \pm 22.01^{b}$ & $2.445 \pm 0.022^{b}$ & $2.78 \pm 0.10^{b}$ & $2.78 \pm 0.11^{b}$ & $2.43 \pm 0.21^{b}$ & 0 & EVOO \\
\hline FS-17 & $0.043 \pm 0.005^{\mathrm{ns}}$ & $562 \pm 7.81^{b}$ & $2.552 \pm 0.011^{\mathrm{ab}}$ & $3.18 \pm 0.15^{\mathrm{a}}$ & $3.18 \pm 0.12^{a b}$ & $2.78 \pm 0.20^{a b}$ & 0 & EVOO \\
\hline
\end{tabular}

$\mathrm{CAE}=$ Caffeic Acid Equivalent; B.I. = Bitterness Index; ${ }^{,}$, Median values; ${ }^{* *}$, UE Regulation 1348/2013; EVOO = Extra Virgin Olive Oil; Values in columns having different letters (a,b,c) are significantly different from one another at $p \leq 0.05$; ${ }^{\text {ns }}$, not significant.

Table 2. Microbiological and enzymatic characteristics of the mixer Leccino EVOO used to blend with Don Carlo EVOO.

\begin{tabular}{|c|c|c|c|c|c|c|c|}
\hline \multirow{2}{*}{$\begin{array}{l}\text { Leccino EVOO } \\
\text { mixer }\end{array}$} & \multirow{2}{*}{$\begin{array}{c}\text { Suspend } \\
\text { Material (\%) }\end{array}$} & \multirow{2}{*}{$\begin{array}{l}\text { Total Polar Phenols } \\
\text { (mg CAE per Kg) }\end{array}$} & \multicolumn{3}{|c|}{ Yeasts } & \multicolumn{2}{|c|}{$\begin{array}{l}\text { Enzymatic Activity of the EVOO } \\
\text { Suspended Materials }\end{array}$} \\
\hline & & & $\begin{array}{c}\text { Total Yeasts } \\
\text { (Log CFU/mL oil) }\end{array}$ & $\begin{array}{c}\beta \text {-Glucosidase-Producing } \\
\text { Yeasts }(\%)\end{array}$ & $\begin{array}{c}\text { Phenoloxidase-Producing } \\
\text { Yeasts (\%) }\end{array}$ & $\begin{array}{c}\beta \text {-Glucosidase } \\
\text { ( } \mu \mathrm{g} p \text {-Nitrophenol/g Solids) }\end{array}$ & $\begin{array}{l}\text { Phenoloxidase } \\
\text { (U/g Solids)* }\end{array}$ \\
\hline Decanter EVOO & $0.053 \pm 0.01^{\mathrm{b}}$ & $158 \pm 0.40$ & $3.15 \pm 0.09^{\text {ns }}$ & $96 \pm 4^{\mathrm{ns}}$ & $3 \pm 1^{\mathrm{ns}}$ & $320.70 \pm 3.5^{\mathrm{b}}$ & $150.20 \pm 5.4^{\mathrm{b} * *}$ \\
\hline Settled EVOO & $0.083 \pm 0.01^{\mathrm{a}}$ & $185 \pm 0.70$ & $3.80 \pm 0.05^{\mathrm{ns}}$ & $98 \pm 9^{\text {ns }}$ & $11 \pm 2^{\text {ns }}$ & $422.62 \pm 4.05^{\mathrm{a}}$ & $235.71 \pm 1.9^{\mathrm{a}}$ \\
\hline
\end{tabular}

EVOO = Extra Virgin Olive Oil; CAE = Caffeic Acid Equivalent; *, U = Enzymatic unit is defined as a 0.01 change per minute in absorbance at 410 nm under given conditions.

**, Mean \pm S.D.; values in columns having different letters ( $a$ and $b$ ) are significantly different from one another at $p \leq 0.05$; ${ }^{\text {ns }}$, not significant. 
Table 3. Microbiological and enzymatic analyses of Don Carlo EVOO blended with decanter or settled Leccino mixer EVOO.

\begin{tabular}{|c|c|c|c|c|c|c|c|}
\hline \multirow[t]{2}{*}{ Blended Don Carlo EVOO } & \multicolumn{2}{|c|}{ Total Yeasts (Log CFU/mL Oil) } & \multicolumn{2}{|c|}{$\begin{array}{c}\beta \text {-Glucosidase-Producing } \\
\text { Yeasts }(\%)\end{array}$} & \multicolumn{2}{|c|}{$\begin{array}{l}\text { Phenoloxidase-Producing } \\
\text { Yeasts (\% of Total Number) }\end{array}$} & \multirow[t]{2}{*}{$\begin{array}{l}\text { Representative Species } \\
\text { at } 3 \text { Months of Storage }\end{array}$} \\
\hline & Time Zero & 3 Months & Time Zero & 3 Months & Time Zero & 3 Months & \\
\hline Unmixed Don Carlo EVOO in vertically fixed canister & $1.80 \pm 0.07^{\mathrm{b} *}$ & $1.30 \pm 0.25^{\mathrm{b}}$ & $92 \pm 4^{\mathrm{ns}}$ & $90 \pm 9^{\text {ns }}$ & $11 \pm 0.8^{\mathrm{ns}}$ & $7 \pm 0.3^{\mathrm{ns}}$ & Candida adriatica \\
\hline Unmixed Don Carlo EVOO in periodically inverted canister & $1.80 \pm 0.07^{b}$ & $1.88 \pm 0.13^{\mathrm{b}}$ & $92 \pm 10^{\text {ns }}$ & $95 \pm 6^{\mathrm{ns}}$ & $11 \pm 0.8^{\mathrm{ns}}$ & $15 \pm 0.2^{\mathrm{ns}}$ & Candida adriatica \\
\hline Blend Don Carlo+ Decanter & $2.60 \pm 0.15^{\mathrm{a}}$ & $1.80 \pm 0.19^{\mathrm{ab}}$ & $95 \pm 5^{\mathrm{ns}}$ & $97 \pm 8^{\mathrm{ns}}$ & $12 \pm 0.5^{\mathrm{ns}}$ & $13 \pm 0.7^{\mathrm{ns}}$ & Candida adriatica \\
\hline EVOO in vertically fixed canister & & & & & & & Candida diddensiae \\
\hline Blend Don Carlo+ Decanter & $2.60 \pm 0.15^{\mathrm{a}}$ & $2.44 \pm 0.26^{\mathrm{a}}$ & $95 \pm 13^{\mathrm{ns}}$ & $98 \pm 5^{\mathrm{ns}}$ & $12 \pm 0.5^{\mathrm{ns}}$ & $18 \pm 0.9^{\mathrm{ns}}$ & Candida adriatica \\
\hline EVOO in periodically inverted canister & & & & & & & Candida diddensiae \\
\hline Blend Don Carlo+ Settled & $2.87 \pm 0.18^{\mathrm{a}}$ & $1.98 \pm 0.13^{\mathrm{ab}}$ & $96 \pm 11^{\mathrm{ns}}$ & $98 \pm 7^{\text {ns }}$ & $14 \pm 0.9^{\mathrm{ns}}$ & $10 \pm 0.4^{\mathrm{ns}}$ & Candida adriatica \\
\hline EVOO in vertically fixed canister & & & & & & & Candida diddensiae \\
\hline $\begin{array}{l}\text { Blend Don Carlo+ Settled } \\
\text { EVOO in periodically inverted canister }\end{array}$ & $2.87 \pm 0.18^{\mathrm{a}}$ & $2.50 \pm 0.18^{\mathrm{a}}$ & $96 \pm 12^{\mathrm{ns}}$ & $100 \pm 9$ ns & $14 \pm 0.9^{\mathrm{ns}}$ & $19 \pm 0.5^{\mathrm{ns}}$ & $\begin{array}{l}\text { Candida adriatica } \\
\text { Candida diddensiae }\end{array}$ \\
\hline
\end{tabular}

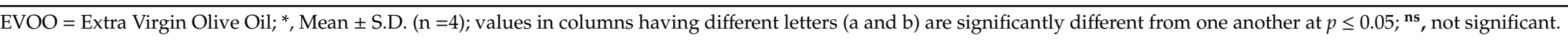

Table 4. Total polar phenol content and decay in Bitterness Index in the unmixed and blended Don Carlo EVOO during storage.

\begin{tabular}{|c|c|c|c|c|c|c|c|c|c|c|}
\hline \multirow[b]{2}{*}{ Blend Don Carlo EVOO } & \multicolumn{4}{|c|}{ Time Zero } & \multicolumn{6}{|c|}{ Three Months Storage } \\
\hline & $\begin{array}{l}\text { Total Polar Phenols } \\
\text { (mg CAE per kg) }\end{array}$ & $\Delta^{*}(\%)$ & B.I. $\left(\mathrm{ABS}_{225}\right)$ & $\Delta(\%)$ & $\begin{array}{l}\text { Total Polar Phenols } \\
\text { (mg CAE per kg) }\end{array}$ & $\Delta$ & $\Delta^{* *}$ & B.I. $\left(\mathrm{ABS}_{225}\right)$ & $\Delta$ & $\triangle$ \\
\hline $\begin{array}{l}\text { Unmixed Don Carlo oil in } \\
\text { vertically fixed canister }\end{array}$ & $708 \pm 10.01^{\mathrm{a}}$ & 0 & $2.771 \pm 0.0001^{\mathrm{a}}$ & 0 & $617.38 \pm 12.28^{a}$ & 0 & 13 & $2.468 \pm 0.007^{\mathrm{a}}$ & 0 & 11 \\
\hline $\begin{array}{l}\text { Unmixed Don Carlo oil in } \\
\text { periodically inverted canister }\end{array}$ & $708 \pm 10.01^{\mathrm{a}}$ & 0 & $2.771 \pm 0.001^{\mathrm{a}}$ & 0 & $610.07 \pm 4.21^{\mathrm{a}}$ & 0 & 14 & $2.453 \pm 0.036^{\mathrm{a}}$ & 0 & 12 \\
\hline $\begin{array}{l}\text { Blend Don Carlo+ Decanter oil in } \\
\text { vertically fixed canister }\end{array}$ & $600 \pm 7.32^{b}$ & 15 & $2.309 \pm 0.030^{b}$ & 17 & $527.05 \pm 7.32^{\mathrm{a}}$ & 15 & 12 & $2.247 \pm 0.03^{\mathrm{ab}}$ & 9 & 3 \\
\hline $\begin{array}{l}\text { Blend Don Carlo+ Decanter oil in } \\
\text { periodically inverted canister }\end{array}$ & $600 \pm 7.32^{b}$ & 15 & $2.309 \pm 0.030^{b}$ & 17 & $450.91 \pm 5.11^{b}$ & 26 & 25 & $2.119 \pm 0.033^{\mathrm{ab}}$ & 14 & 8 \\
\hline $\begin{array}{l}\text { Blend Don Carlo+ Settled oil in } \\
\text { vertically fixed canister }\end{array}$ & $588 \pm 10.20^{b}$ & 17 & $2.301 \pm 0.020^{b}$ & 17 & $411.48 \pm 5.26^{b}$ & 33 & 30 & $1.784 \pm 0.021^{\mathrm{b}}$ & 28 & 22 \\
\hline $\begin{array}{l}\text { Blend Don Carlo+ Settled oil in } \\
\text { periodically inverted canister }\end{array}$ & $588 \pm 10.20^{b}$ & 17 & $2.301 \pm 0.020^{b}$ & 17 & $285.74 \pm 6.41^{c}$ & 53 & 51 & $1.339 \pm 0.027^{c}$ & 45 & 42 \\
\hline
\end{tabular}

EVOO = Extra Virgin Olive Oil; CAE = Caffeic Acid Equivalent; B.I. = Bitterness Index; $\Delta^{*}$, Decay compared to unmixed Don Carlo EVOO stored vertically in fixed or periodically inverted canisters, respectively; $\Delta^{* *}$, decay compared to time zero; mean \pm S.D. $(\mathrm{n}=4)$; values in columns having different letters $(\mathrm{a}, \mathrm{b}$ and $\mathrm{c})$ are significantly different from one another at $p \leq 0.05$. 
Table 5. Sensory profile of unmixed and blended Don Carlo EVOO after three months of storage.

\begin{tabular}{|c|c|c|c|c|c|c|c|c|}
\hline Blended Don Carlo EVOO & Fruitiness & $\Delta^{*}(\%)$ & Bitterness & $\triangle(\%)$ & Pungency & $\Delta$ & Defects & Merceological Class \\
\hline Unmixed Don Carlo oil in vertically fixed canister & $4.0 \pm 0.1^{* *}$ & 0 & $4.8 \pm 0.2^{\mathrm{a}}$ & 0 & $3.5 \pm 0.3^{\mathrm{a}}$ & 0 & 0 & EVOO \\
\hline Unmixed Don Carlo oil in periodically inverted canister & $3.5 \pm 0.2$ & 0 & $4.5 \pm 0.4^{\mathrm{a}}$ & 0 & $3.5 \pm 0.2^{\mathrm{a}}$ & 0 & 14 & EVOO \\
\hline Blend Don Carlo+ Decanter oil in vertically fixed canister & $3.5 \pm 0.4$ & 13 & $3.5 \pm 0.1 \mathrm{ab}$ & 27 & $3.3 \pm 0.2^{\mathrm{a}}$ & 6 & 0 & EVOO \\
\hline Blend Don Carlo+ Decanter oil in periodically inverted canister & $3.0 \pm 0.2$ & 14 & $2.0 \pm 0.2^{b}$ & 55 & $2.8 \pm 0.3^{\mathrm{ab}}$ & 20 & 0 & EVOO \\
\hline Blend Don Carlo+ Settled oil in vertically fixed canister & $3.8 \pm 0.1$ & 5 & $2.5 \pm 0.2^{b}$ & 48 & $2.5 \pm 0.1^{\mathrm{b}}$ & 29 & 0 & EVOO \\
\hline Blend Don Carlo+ Settled oil in periodically inverted canister & $3.2 \pm 0.2$ & 9 & $1.0 \pm 0.1^{\mathrm{c}}$ & 80 & $2.6 \pm 0.2^{b}$ & 26 & 0 & EVOO \\
\hline \multicolumn{9}{|c|}{$\begin{array}{l}\text { EVOO = Extra Virgin Olive Oil; * Decay compared to unmixed Don Carlo EVOO stored in vertically fixed or periodically inverted canisters, respectively; ** Median of the values; Values in } \\
\text { columns having different letters (a,b and c) are significantly different from one another at } p \leq 0.05 .\end{array}$} \\
\hline Blended Don Carlo EVOO & $\begin{array}{c}\text { Acidity } \\
\text { (\% oleic acid) }\end{array}$ & $\begin{array}{l}\text { N. of P } \\
\text { (mg O }\end{array}$ & $\begin{array}{l}\text { coxides } \\
\text { kg oil) }\end{array}$ & $\mathbf{K}_{232}$ & $\mathbf{K}_{2}$ & & $\Delta \mathrm{K}$ & Merceological Class \\
\hline Unmixed Don Carlo oil in canister vertical fixed & $0.23 \pm 0.03^{\mathrm{b}}$ & 5.30 & $0.42^{\mathrm{b}}$ & $2.177 \pm 0.00^{\mathrm{ns}}$ & $0.196 \pm$ & $01^{\text {ns }}$ & $-0.004^{\mathrm{ns}}$ & EVOO \\
\hline Unmixed Don Carlo oil in canister periodically inverted & $0.27 \pm 0.06^{\mathrm{b}}$ & 5.90 & $0.60^{\mathrm{b}}$ & $2.407 \pm 0.007^{\mathrm{ns}}$ & $0.198 \pm$ & $01^{\text {ns }}$ & $-0.004^{\mathrm{ns}}$ & EVOO \\
\hline Blend Don Carlo+ Decanter oil in canister vertical fixed & $0.30 \pm 0.01^{\mathrm{ab}}$ & $7.70 \pm$ & $.32^{\mathrm{ab}}$ & $2.100 \pm 0.007^{\mathrm{ns}}$ & $0.164 \pm$ & $03^{\text {ns }}$ & $-0.003^{\text {ns }}$ & EVOO \\
\hline Blend Don Carlo+ Decanter oil in canister periodically inverted & $0.45 \pm 0.03^{\mathrm{a}}$ & 8.70 & $0.28^{\mathrm{a}}$ & $2.170 \pm 0.00^{\mathrm{ns}}$ & $0.184 \pm$ & $04^{\text {ns }}$ & $-0.003^{\text {ns }}$ & EVOO \\
\hline Blend Don Carlo+ Settled oil in canister vertical fixed & $0.28 \pm 0.01^{\mathrm{b}}$ & 5.60 & $0.30^{\mathrm{b}}$ & $2.151 \pm 0.003^{\mathrm{ns}}$ & $0.182 \pm$ & $02^{\text {ns }}$ & $-0.004^{\mathrm{ns}}$ & EVOO \\
\hline Blend Don Carlo+ Settled oil in canister periodically inverted & $0.48 \pm 0.01^{\mathrm{a}}$ & 9.60 & $0.28^{\mathrm{a}}$ & $2.181 \pm 0.002^{\mathrm{ns}}$ & $0.188 \pm$ & $03^{\text {ns }}$ & $-0.004^{\mathrm{ns}}$ & EVOO \\
\hline Limit values allowed for the EVOO by the EC Regulation & 0.80 & & & 2.50 & 0. & & 0.01 & \\
\hline
\end{tabular}

EVOO = Extra Virgin Olive Oil; Mean \pm S.D. $(\mathrm{n}=4)$; Values in columns having different letters ( $\mathrm{a}$ and $\mathrm{b}$ ) are significantly different from one another at $p \leq 0.05$; ${ }^{\text {ns }}$, not significant. 


\section{Conclusions}

The enzymatic debittering method used in this study could offer a means of opening new markets for monocultivar phenol-rich EVOOs. The bitter and phenol-rich oils, normally used to increase the phenolic concentration of other oils, can be improved in their sensory aspects, and marketed for direct consumption. Compared to the traditional racking technique, carried out by storing the newly produced EVOO in tanks for 5-6 months, the enzymatic system used in this work allows to significantly reduce the debittering time of olive oil. In fact, three months of incubation with the settled Leccino EVOO mixer yielded the best performance in reducing the bitter taste of Don Carlo EVOO.

The debittering process of Don Carlo EVOO blended with Leccino EVOO can be further shortened if the oil containers are periodically inverted to prevent sedimentation of the suspended enzyme and oleuropeinolytic yeast rich material. The excessively bitter and phenol rich Don Carlo EVOO, mixed with decanter or settled Leccino EVOO, did not develop any negative sensory attributes during the three month debittering process, remaining in the EVOO merceological class. The enzymatic debittering system of the newly produced EVOO could have interesting application in the future, since not being they subjected to further chemical treatments, the blended olive oils, in according with the European Community Regulation, can be marketed as EVOO. However, considering the lack of studies conducted so far on this topic and the different composition of the EVOOs, further research is needed to better understand the survival of the microbiota of each monocultivar EVOO, in blended olive oil during storage.

Author Contributions: Oil sampling, S.P.; investigation, B.A.Z., S.P. and G.C.; methodology, B.A.Z. and G.C.; writing and original draft, B.A.Z. and G.C. All authors have read and agreed to the published version of the manuscript.

Funding: This research received no external funding.

Conflicts of Interest: The authors declare no conflict of interest.

\section{References}

1. Cicerale, S.; Lucas, L.J.; Keast, R.S. Antimicrobial, antioxidant and anti-inflammatory phenolic activities in extra virgin olive oil. Curr. Opin. Biotechnol. 2012, 23, 129-135. [CrossRef] [PubMed]

2. European Food safety Authority (EFSA). Polyphenols in olive oil related health claims. Regulation (EC) N. 1924/2006. EFSA J. 2011, 9, 2044.

3. Koidis, A.; Triantafillou, E.; Boskou, D. Endogenous microflora in turbid virgin olive oils and the physicochemical characteristics of these oils. Eur. J. Lipid Sci. Technol. 2008, 110, 164-171. [CrossRef]

4. Papadimitriou, V.; Dulle, M.; Wachter, W.; Sotiroudis, T.G.; Glatter, O.; Xenakis, A. Structure and dynamics of veiled virgin olive oil: Influence of production conditions and relation to its antioxidant capacity. Food Biophys. 2013, 8, 112-121. [CrossRef]

5. Veneziani, G.; Esposto, S.; Minnocci, A.; Taticchi, A.; Urbani, S.; Selvaggini, R.; Sordini, B.; Servili, M. Compositional differences between veiled and filtered virgin olive oils during a simulated shelf life. LWT Food Sci. Tech. 2018, 94, 87-95. [CrossRef]

6. Ciafardini, G.; Zullo, B.A. Microbiological activity in stored olive oil. Int. J. Food Microbiol. 2002, 75, 111-118. [CrossRef]

7. Lercker, G.; Frega, N.; Bocci, F.; Servidio, G. "Veiled" extra-virgin olive oils: Dispersion response related to oil quality. J. Am. Oil Chem. Soc. 1994, 71, 657-658. [CrossRef]

8. Koidis, A.; Boskou, D. The contents of proteins and phospholipids in veiled (cloudy) olive oils. Eur. J. Lipid Sci. Technol. 2006, 108, 323-328. [CrossRef]

9. Georgalaki, M.D.; Sotiroudis, T.G.; Xenakis, A. The presence of oxidizing enzyme activities in virgin olive oil. J. Am. Oil Chem. Soc. 1998, 75, 155-159. [CrossRef]

10. Soler-Rivas, J.C.; Espín, C.; Wichers, H.J. Review oleuropein and related compounds. J. Sci. Food Agric. 2000, 80, 1013-1023. [CrossRef] 
11. Dierkes, G.; Krieger, S.; Dück, R.; Bongartz, A.; Schmitz, O.J.; Hayen, H. “High-performance liquid chromatography-mass spectrometry profiling of phenolic compounds for evaluation of olive oil bitterness and pungency". J. Agric. Food. Chem. 2012, 60, 7597-7606. [CrossRef] [PubMed]

12. Franco, M.N.; Galeano-Díaz, T.; López, O.; Fernández-Bolaños, J.G.; Sánchez, J.; De Miguel, C.; Gil, M.V.; Martín-Vertedor, D. Phenolic compounds and antioxidant capacity of virgin olive oil. Food Chem. 2014, 163, 289-298. [CrossRef] [PubMed]

13. Mateos, R.; Cert, A.; Pérez-Camino, M.C.; García, J.M. Evaluation of virgin olive oil bitterness by quantification of secoiridoid derivatives. J. Am. Oil Chem. Soc. 2004, 81, 71-75. [CrossRef]

14. Peres, F.; Martins, L.L.; Ferreira-Dias, S. Influence of enzymes and technology on virgin olive oil composition. Crit. Rev. Food Sci. Nutr. 2017, 57, 3104-3126. [CrossRef] [PubMed]

15. Montedoro, G.F.; Servili, M.; Baldioli, M.; Selvaggini, R.; Miniati, E.; Macchioni, A. Simple and hydrolyzable compounds in virgin olive oil: Spectroscopic characterization of the secoiridoid derivatives. J. Agric. Food Chem. 1993, 41, 2228-2234. [CrossRef]

16. Botìa, J.; Ortuno, M.A.; Benavente-Garcìa, O.; Bàidez, A.G.; Frìas, J.; Marcos, D.; Del Rio, J.A. Modulation of the biosynthesis of some phenolic compounds in Olea europea L. fruits: Their influence on olive oil quality. J. Agric. Food Chem. 2001, 49, 355-358. [CrossRef]

17. Ciafardini, G.; Zullo, B.A.; Cioccia, G.; Iride, A. Lipolytic activity of Williopsis californica and Saccharomyces cerevisiae in extra virgin olive oil. Int. J. Food Microbiol. 2006, 107, 27-32. [CrossRef]

18. Zullo, B.A.; Cioccia, G.; Ciafardini, G. Effects of some oil-born yeasts on the sensory characteristics of Italian virgin olive oil during its storage. Food Microbiol. 2013, 36, 70-78. [CrossRef]

19. Ciafardini, G.; Zullo, B.A. Virgin olive oil yeasts: A review. Food Microbiol. 2018, 70, 245-253. [CrossRef]

20. Gutiérrez Rosales, F.; Perdiguero, S.; Olias, J.M. Evaluation of the bitter taste in virgin olive oil. J. Am. Oil Chem. Soc. 1992, 64, 394-395. [CrossRef]

21. Garcia, J.M.; Yousti, K.; Oliva, J.; García-Diaz, M.T.; Pérez-Camino, M.C. Hot water dipping of olives (Olea europaea) for virgin oil debittering. J. Agric. Food Chem. 2005, 53, 8248-8252. [CrossRef] [PubMed]

22. Yousfi, K.; Moyano, M.J.; Martinez, F.; Cayuela, J.A. Postharvest heat treatment for olive oil debittering at the industrial scale. J. Am. Oil Chem. Soc. 2010, 87, 1053-1061. [CrossRef]

23. Abenoza, M.; Raso, J.; Oria, R.; Sánchez-Gimeno, A.C. Debittering olive oil by liquid-liquid extraction: Kinetics and the effect on the quality of Arbequina olive oil. Eur. J. Lipid Sci. Technol. 2015, 118, 1243-1249. [CrossRef]

24. Abenoza, M.; Raso, J.; Oria, R.; Sánchez-Gimeno, A.C. Modulating the bitterness of Empeltre olive oil by partitioning polyphenols between oil and water phases: Effect on quality and shelf life. Food Sci. Technol. Int. 2018, 25, 47-55. [CrossRef] [PubMed]

25. Uceda, M.; Hermoso, M. La calidad del aceite de oliva. In El Cultivo del Olivo; Barranco, D., Fernandez-Escobar, R., Rallo, L., Eds.; Mundi-Prensa: Madrid, Spain, 2001; pp. 589-614.

26. Zullo, B.A.; Ciafardini, G. Distribution of dimorphic yeast species in commercial extra virgin olive oil. Food Microbiol. 2010, 27, 1035-1042. [CrossRef]

27. Kurtzman, C.P.; Fell, J.W. The Yeasts, a Taxonomic Study; Elsevier: Amsterdam, The Netherlands, 1998; pp. 320-351.

28. Sambrock, J.; Fritsch, E.F.; Maniatis, T. Molecular Cloning, a Laboratory Manual, 2nd ed.; Cold Spring Harbor Laboratory Press: New York, NY, USA, 1989; pp. 1814-1875.

29. Tornai-Lehoczki, J.; Peter, G.; Dlauchy, D. CHROMagar Candida medium as 468 a practical tool for the differentiation and presumptive identification of yeast species isolated from salad. Int. J. Food Microbiol. 2003, 86, 180-200. [CrossRef]

30. Kurtzman, C.P.; Robnett, C.J. Identification of clinical important ascomycetous yeast based on nucleotide divergence in the $5^{\prime}$ end of the large-subunit (26S) ribosomal DNA gene. J. Clin. Microbiol. 1997, 5, 1216-1223. [CrossRef]

31. European Commission Regulation No. 1348/2013 of 16 December Amending 2013 Regulation (EEC) No. 2568/91 on the Characteristics of Olive Oil and Olive Residue Oil and on the Relevant Methods of Analysis.

32. EN ISO/IEC 17025/2005.; General Requirement for the Competence of Testing and Calibration Laboratories International Olive Council (2007) Sensory Analysis of Olive Oil-method for the Organoleptic Assessment of Virgin Olive Oil. 2005, IOC/T.20/Doc. No.15/Rev.2. 
33. Gutiérrez-Rosales, F.; Ríos, J.J.; Gómez-Rey, M.L. Main polyphenols in the bitter taste of virgin olive oil. Structural confirmation by on-line high-performance liquid chromatography electrospray ionization mass spectrometry. J. Agric. Food Chem. 2003, 51, 6021-6025. [CrossRef]

34. Beltrán, G.; Ruano, M.T.; Jiménez, A.; Uceda, M.; Aguilera, M.P. Evaluation of virgin olive oil bitterness by total phenol content analysis. Eur. J. Lipid Sci. Technol. 2007, 109, 193-197. [CrossRef]

35. Ciafardini, G.; Cioccia, G.; Zullo, B.A. Survival of Candida parapsilosis yeast in olive oil. Ann. Microbiol. 2013, 63, 1645-1648. [CrossRef]

36. Zullo, B.A.; Ciafardini, G. Changes in physicochemical and microbiological parameters of short and long-lived veiled (cloudy) virgin olive oil upon storage in the dark. Eur. J. Lipid Sci. Tech. 2018, 120, 1700309. [CrossRef]

(C) 2020 by the authors. Licensee MDPI, Basel, Switzerland. This article is an open access article distributed under the terms and conditions of the Creative Commons Attribution (CC BY) license (http://creativecommons.org/licenses/by/4.0/). 